\title{
Branched Secondary Alcohol Ethoxylate, Ammonium Thiosulfate, Calcium polysulfides-thiosulfate, and Fish Oil Effects on Blossom Thinning, Fruit Set and Quality of Peaches and Nectarines
}

\author{
Esmaeil Fallahi $^{1 *}$, Amir A Khoddamzadeh², Bahar Fallahi ${ }^{1}$ and Shahla Mahdavi ${ }^{1}$ \\ ${ }^{1}$ Department of Plant Sciences, Parma Research and Extension Center, University of Idaho, USA \\ ${ }^{2}$ Department of Earth \& Environment, Florida International University, USA
}

\begin{abstract}
Total crop load has an inverse relationship with fruit size, while larger fruit size is often demanded by the peach and nectarine markets. Hand-thinning is extremely expensive, and thus, crop load adjustment, using blossom thinners is a crucial practice to ensure production of commercially acceptable fruit size and yield efficiency in stone fruit. In this study, the influence of branched secondary alcohol ethoxylate (Tergitol TMN-6), ammonium thiosulfate (ATS), Crocker Fish Oil, (FO) and a mixture of calcium polysulfides and thiosulfate (lime sulfur) on fruit set and quality attributes in peaches (Prunus persica) and nectarines ( $P$. persica var. nectarina) were studied. All blossom thinners reduced fruit set in 'Summer Lady' peach in both 2016 and 2017. Fruit sets in 'Summer Lady' peach trees with a double application of Tergitol TMN-6 at the rate of 7.5 or $10 \mathrm{~mL}^{-L^{-1}}$, each rate applied at $40 \%$ and $80 \%$ bloom, were lower than those receiving the same rates of this chemical only at $80 \%$ bloom, but they were similar to those receiving a single Tergitol TMN-6 spray at $15 \mathrm{~mL} . \mathrm{L}^{-1}$ at $80 \%$ or $100 \%$ bloom. 'Summer Lady' peach trees receiving Fish Oil at $20 \mathrm{~mL}^{-L^{-1}}$ plus lime sulfur at $25 \mathrm{~mL}^{-L^{-1}}$, once at $40 \%$ bloom and again at $80 \%$ bloom had lower fruit set as compared to Un-treated Control but the fruit set was higher than those with any Tergitol-TMN-6 spray. Tergitol TMN-6 at $12 \mathrm{~m}^{-1}$ at $100 \%$ bloom or $10 \mathrm{~mL} . \mathrm{L}^{-1}$ all stages of bloom reduced fruit set in 'Zee Lady and Snow Giant' peaches. Total yield was proportional to the severity of thinning and final fruit weight. In 'Snow Giant' peach, trees receiving Tergitol TMN-6 at all concentrations and blossom stages had significantly higher fruit weight as compared to the trees of Un-treated Control. Applications of Tergitol TMN- 6 at all concentrations at $80 \%$ bloom reduced fruit set in 'Red Globe' and 'Elberta' peaches in Utah comparing with Un-treated Control. Overall, it is concluded that efficacy of blossom thinners depends on the rate of thinners, cultivar and stage of bloom development.
\end{abstract}

\section{Keywords}

Crop regulation, Fruit thinning, Stone fruit, Regular cropping

\section{Introduction}

Hand-thinning is a critical cultural practice that increase the leaf-to-fruit ratio and leads to the production of larger fruit size in apples and peaches, as well as reduction of the biennial bearing in apples [1-4]. Most blossom thinners are caustic and reduce fruit set by damaging different flower parts, including anthers, stigmas, styles, and pollen tubes, and thus prevent fertilization [4].

Hydrogen cyanamide (Dormex, 50\% a.i.) was initially used to reduce dormancy requirement in 'Florda Prince' peach [5]. In later studies, Dormex was also found to be an effective blossom thinner for plums [6] and peach [2] in Idaho. Full-bloom

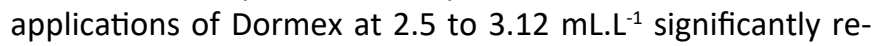
duced fruit set in 'Flavorcrest' peach [7]. Comparing efficacy of blossom thinners reveled that Dormex was a more consistent blossom thinner for apple and peach than monocarbam- ide dihydrogen sulfate or sulfcarbamide (Wilthin, 79\%, a.i.), 7 , oxybicylo $(2,2,2)$ heptane-2-3 dicarboxcylic acid (Endothall, $0.5 \%$ a.i.; an aquatic herbicide), and pelargonic acid (Thinex) $[2,3]$. Endothall at a rate of $1.87 \mathrm{~mL} \cdot \mathrm{L}^{-1}$ formulation was found

*Corresponding author: Esmaeil Fallahi, Department of Plant Sciences, University of Idaho, Parma Research and Extension Center, Professor and Director of Pomology and Viticulture Program, 29603 U of I Lane, Parma, Idaho 83660, USA

Accepted: November 24, 2020

Published online: November 26, 2020

Citation: Fallahi E, Khoddamzadeh AA, Fallahi B, et al. (2020) Branched Secondary Alcohol Ethoxylate, Ammonium Thiosulfate, Calcium polysulfides-thiosulfate, and Fish Oil Effects on Blossom Thinning, Fruit Set and Quality of Peaches and Nectarines. J Hortic Sci Res 3(1):125-134 
Citation: Fallahi E, Khoddamzadeh AA, Fallahi B, et al. (2020) Branched Secondary Alcohol Ethoxylate, Ammonium Thiosulfate, Calcium polysulfides-thiosulfate, and Fish Oil Effects on Blossom Thinning, Fruit Set and Quality of Peaches and Nectarines. J Hortic Sci Res 3(1):125-134

to effectively thin 'Redhaven' peach blossoms when applied at stages of $85 \%-90 \%$ open bloom [2]. In field trials in Washington, California, and Idaho, Endothall was an effective blossom thinner for apples and stone fruit $[2,8]$. However, Endothall was ineffective when applied at $100 \%$ bloom, when most flowers were already fertilized [2]. Wilthin has been used for blossom thinning in stone fruit, including peaches [8-10], and plums [9]. On 'Friar' plum, full-bloom application of Wilthin at $10 \mathrm{~mL}^{-1}$ plus polyoxyethylenepolypropoxypropanol (Regulaid with $90.6 \%$ a.i) at $1.25 \mathrm{~mL}^{-1}$, using a hand-gun sprayer, increased the fruit size [4]. In a comparison of ammonium thiosulfate (ATS), Wilthin, and Endothall, ATS was proved to be the best blossom thinner under Washington conditions [8]. Full-bloom application of the surfactant N, N-bis2-(omegahydroxypolyoxyethylenepoly-oxypropylene) ethyl alkylamine (Armothin) at $30 \mathrm{~mL} . \mathrm{L}^{-1}$ or $5 \mathrm{~mL} . \mathrm{L}^{-1}$ reduced fruit set in 'Loadel' peach in California [11].

Surfactant 2,6,8-trimethyl-4-nonyloxypolyethyleneoxyethanol (Tergitol) TMN-6 (90\% aq.) was at least one of the putative active ingredients of Surfactant WK, a surfactant that was labeled by DOW Chemical Company [12]. In contrast to most other blossom thinners which are only toxic to pistils and/or stamens, Tergitol TMN-6 killed peach flowers by killing peduncles and pistils [12]. Fallahi, et al. [13] reported that Tergitol TMN-6 at the rate of $5 \mathrm{~mL} . \mathrm{L}^{-1}$, applied at $75 \%$ to $85 \%$ bloom, reduced fruit set in peaches under conditions of southern Idaho, USA. Wilkins, et al. [14] reported that Tergitol TMN-6 effectively reduced fruit set in 'Fireprince' peach under climatic conditions of Clanton, Alabama. In that report, there was no difference in thinning response at full bloom or petal fall, suggesting a wide window of efficacy for this chemical. Searching for new blossom thinners, Miller and Tworkoski [15] reported that application of eugenol at $8 \%$ and $10 \%$ caused major caustic effects but application of this compound at $1 \%$ or $2 \%$ showed promising results on peach blossom thinning.

Rex lime sulfur (29\% calcium polysulfide) at $3 \%$ plus $2 \%$ JMS stylet oil caused significant russeting and reduced pack out, whereas low rates (e.g. $1 \%$ lime sulfur and $1 \% \mathrm{JMS}$ stylet oil) had no significant thinning effect in apples under conditions of West Virginia [16]. In that report, spraying 1.5\%-2\% Rex lime sulfur and $2 \%$ oil showed acceptable thinning results and less fruit russeting in apples [16].

Choosing a reliable blossom thinner for peaches and nectarines is a risky task. Based on author's experience (Fallahi, unpublished data), three major risks are associated with blossom thinning of stone and pome fruits, including: 1) Occurrence of severe frost after blossom thinning application; 2) Over thinning due to high rates of blossom thinners and/or unfavorable temperature changes before, during and after applications of blossom thinners; 3) Application in a season that bee activity was limited, due to low temperatures and high wind, resulting in poor fruit set; 4) Creation of 'rough' fruit finish or russeting due to aggravation of the fruit cuticle by the blossom thinner and/or high temperatures and fast expansion of fruit surface. Despite these risks, fruit growers are increasing forced to choose a method in addition to hand thinning to reduce the fruit load. The cost hand thinning is be- tween $\$ 1800$ to $\$ 3400$ per ha and finding specialized fruit labor force is becoming extremely difficult. These issues would increase the cost of fruit production and marginalizes the net return. Therefore, the goal of this study was to determine efficacy of Tergitol TMN-6, lime sulfur, ammonium thiosulfate, fish oil on blossom thinning, fruit quality, and yield in different peach and one nectarine cultivars under conditions of southwest, USA.

\section{Materials and Methods}

\section{General experimental design, orchard condi- tions, and methods for stone fruits}

Blossom thinning studies were conducted on peaches [(Prunus persica (L.) Batsch] in five orchards in 2016 (one at Symms Fruit Ranch in Sunny Slope, Idaho, two at the University of Idaho, Parma, Idaho, and two orchards near Ogden, Utah). The same Idaho peach orchards used in 2016, were also used in 2017 bloom thinning studies. Blossom thinning was also conducted in one nectarine nectarines ( $P$. persica var. nectarina) orchard at Williamson Orchards in Sunny Slope, Idaho in 2016. Soil structure in all experimental orchards was sandy loam with a $\mathrm{pH}$ of about 7.5. Other than blossom thinning treatments, cultural practices in these orchards were generally similar to those recommended for the Pacific Northwest orchards Washington State University [17].

The peach orchards at Symms Fruit Ranch Sunny Slope, Idaho, in both years had seven-year old trees of 'Summer Lady' on Lovell rootstock, planted at $3.52 \times 5.79$ m spacing. Each of the two orchards used at the University of Idaho near Parma, Idaho was a five-year old 'Zee Lady' or 'Snow Giant' peach on Lovell rootstock, and trees were planted at $2.44 \times$ $5.03 \mathrm{~m}$ spacing. In Utah, five-year old orchards of 'Red Globe' and 'Elberta' peaches on Lovell rootstock, each with a tree spacing of $3 \times 4 \mathrm{~m}$ were used for the blossom thinning experiment in 2016. Nectarine blossom thinning was conducted in a five-year old orchard of 'Diamond Ray' nectarine on Lovell rootstock with a $3 \times 4.5 \mathrm{~m}$ tree spacing in 2016. Trees of 'Zee Lady' and 'Snow Giant' peaches were trained into a perpendicular V. Other experimental trees were pruned as open vase shape with four to five main scaffolds.

On different sides of each tree, six fruit-bearing hangers or branches were randomly selected and tagged at their basal points. For fruit set measurement, number of flower buds on each of the selected hangers was counted about 7 days before bloom (before any treatment application). The total number of fruits on these tagged hangers or branches was counted after "June drop", and percentage of fruit set was calculated as (fruit number/flower bud number) $\times 100$. After counting fruits, fruits in all treatments were hand thinned at the beginning of pit hardening to maintain about $17 \mathrm{~cm}$ spacing between fruits.

Approximately 40 peach or nectarine per tree were sampled, cleaned, and evaluated for russeting (fruit marks). Thirty of these fruits were used for weight and color measurements. Fruit color was measured by giving a continuous ranking from 1 (green) progressively to 5 (fully developed color). Blossom thinning treatments were as follow: 
Citation: Fallahi E, Khoddamzadeh AA, Fallahi B, et al. (2020) Branched Secondary Alcohol Ethoxylate, Ammonium Thiosulfate, Calcium polysulfides-thiosulfate, and Fish Oil Effects on Blossom Thinning, Fruit Set and Quality of Peaches and Nectarines. J Hortic Sci Res 3(1):125-134

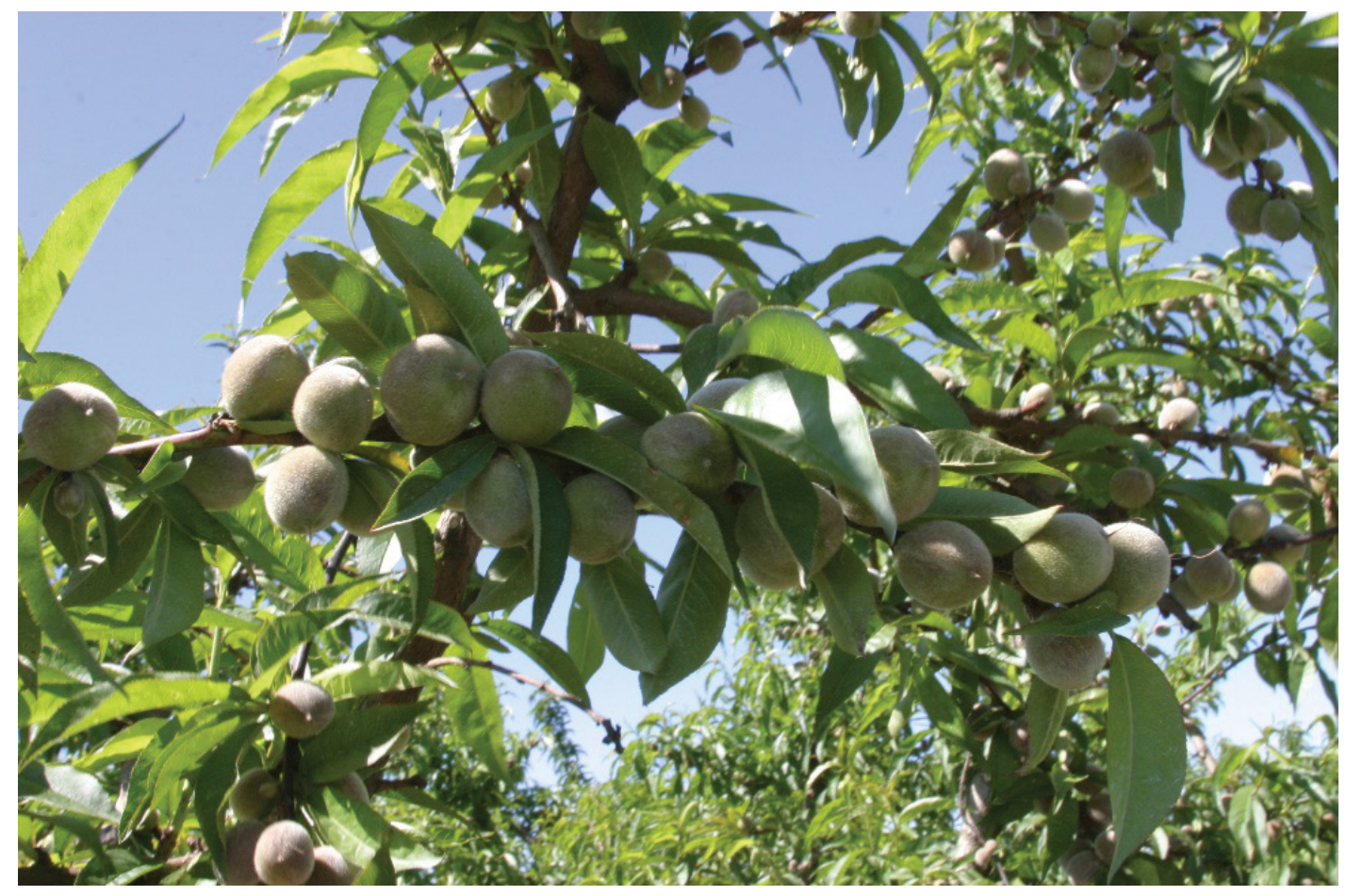

Figure 1: 'Summer Lady' peach before hand-thinning in 2017.

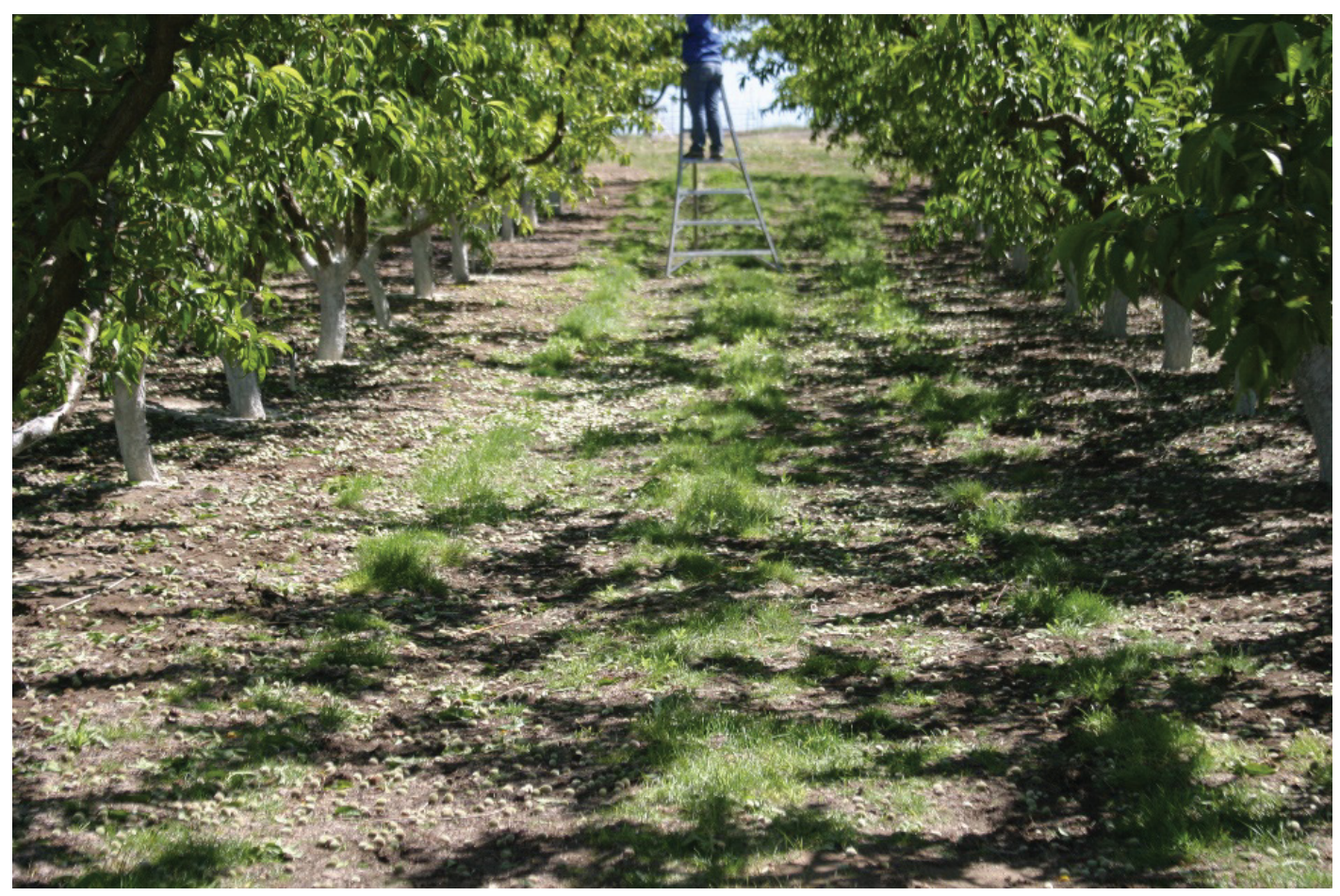

Figure 2: 'Summer Lady' peach orchard floor after hand-thinning,.

\section{A. Treatments at Symms Fruit Ranch, near Caldwell, Idaho} in 2016:

1. Un-treated Control (Figure 1 and Figure 2).

2. Terg7.5 mL.L-1 @80\%Bl, where trees received Tergitol TMN-6 at the rate of $7.5 \mathrm{~m}^{\mathrm{L}^{-1}}$ at $80 \%$ bloom.
3. Terg7.5 mL.L $\mathrm{L}^{-1} @ 40 \% \& 80 \% \mathrm{Bl}$, where trees received Tergitol TMN-6 at 40\% bloom and again at $80 \%$ bloom, each time at the rate of $7.5 \mathrm{~mL} . \mathrm{L}^{-1}$.

4. Terg10 mL.L-1@60\%Bl, where trees received Tergitol TMN-6 at $60 \%$ bloom at the rate of $10 \mathrm{~mL}^{-1}{ }^{-1}$ (Figure 3).

5. Terg10 mL.L-1@ @80\%Bl, where trees received Tergitol 


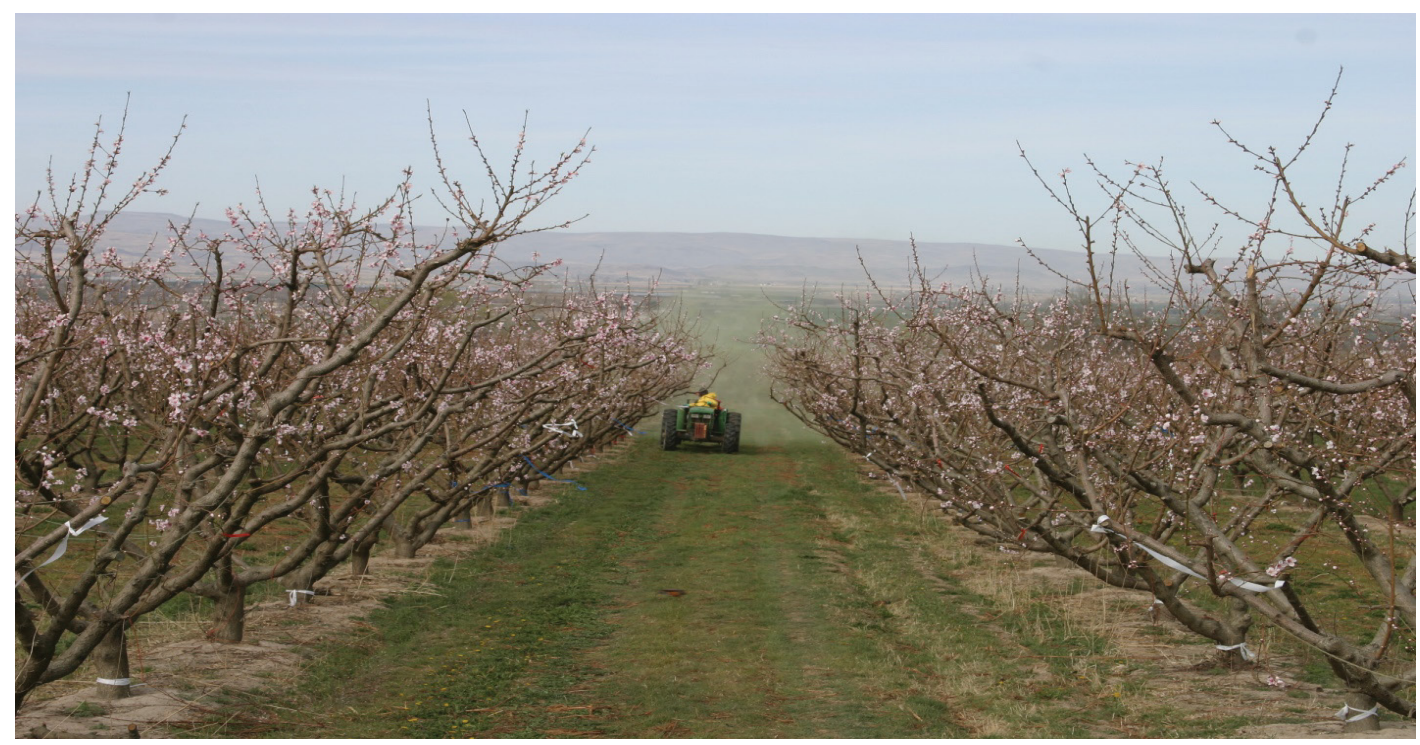

Figure 3: Tergitol TMN-6 spray at 60\% bloom in 'Summer Lady' peach in Sunny Slope, Idaho in 2016.

TMN-6 at $80 \%$ bloom at the rate of $10 \mathrm{~mL} \cdot \mathrm{L}^{-1}$.

6. Terg10 mL.L-1@ 40\&80\%Bl, where trees received Tergitol TMN-6 at $40 \%$ bloom and again at $80 \%$ bloom, each time at the rate of $10 \mathrm{~mL} \cdot \mathrm{L}^{-1}$.

7. Terg10 mL.L-1@100\%Bl, where trees received Tergitol TMN-6 at $100 \%$ bloom at $10 \mathrm{~mL} . \mathrm{L}^{-1}$.

8. Terg15 mL.L-1@ 80\%Bl;, where trees received Tergitol TMN- 6 at $80 \%$ bloom at 15 mL. $\mathrm{L}^{-1}$.

9. Terg15 mL. $\mathrm{L}^{-1} @ 100 \% \mathrm{BI}$, where trees received Tergitol TMN-6 at $100 \%$ bloom at 15 mL.L-1.

\section{B. Treatments on 'Summer Lady' Peach at Symms Fruit} Ranch in 2017:

1. Un-treated Control.

2. Terg7.5 mL.L-1 @80\%Bl, where trees received Tergitol TMN -6 at $80 \%$ bloom at the rate of $7.5 \mathrm{~mL}^{-\mathrm{L}^{-1}}$.

3. Terg10 mL.L ${ }^{-1} @ 80 \% \mathrm{Bl}$, where trees received Tergitol TMN-6 at $80 \%$ bloom at the rate of $10 \mathrm{~mL} \cdot \mathrm{L}^{-1}$.

4. Terg7.5 mL.L ${ }^{-1} @ 40 \% \& 80 \% \mathrm{Bl}$, where trees received Tergitol TMN-6 at $40 \%$ and again at $80 \%$ bloom at the rate $7.5 \mathrm{~mL} . \mathrm{L}^{-1}$.

5. Terg10 mL.L-1 @ 40\%\&80\%BI, where trees received Tergitol TMN-6 at $40 \%$ and again at $80 \%$ bloom, each time at the rate of $10 \mathrm{~mL} \cdot \mathrm{L}^{-1}$.

6. FO20 mL.L-1PlusLS25mL-1 @40\%\&80\%Bl, where trees received Crocker Fish Oil at $20 \mathrm{~mL} . \mathrm{L}^{-1}$ plus Lime sulfur at $25 \mathrm{~m}^{-1}$, applied at $40 \%$ and again at $80 \%$ bloom.

7. LS20 mL.L-1 @40\%\&80\%Bl, where trees received lime sulfur at $20 \mathrm{~m}^{-1}$, applied at $40 \%$ and again at $80 \%$ bloom.

C. Treatments at the University of Idaho, Parma, Idaho 'Zee Lady' and 'Snow Giant' Peaches in 2016:
1. Un-treated Control.

2. Terg10 mL.L-1@60\%Bl, where trees received Tergitol TMN-6 at 60\% bloom in 'Zee Lady' and 'Snow Giant' at the rate of $10 \mathrm{~mL} . \mathrm{L}^{-1}$.

3. Terg10 mL.L-1 @ 80\%Bl, where trees received Tergitol TMN-6 at $80 \%$ bloom in 'Zee Lady' (Figure 4) and 'Snow Giant' at the rate of $10 \mathrm{~mL} . \mathrm{L}^{-1}$.

4. Terg10 mL.L-1 @100\%BI, where trees received Tergitol TMN-6 at 100\% bloom in 'Zee Lady' and 'Snow Giant' at the rate of $10 \mathrm{~mL} . \mathrm{L}^{-1}$.

5. Terg12 mL.L-1 @100\%Bl, where trees received Tergitol TMN-6 at $100 \%$ bloom in 'Zee Lady' and 'Snow Giant' at the rate of $12 \mathrm{~mL} . \mathrm{L}^{-1}$.

D. Treatments at the University of Idaho, Parma, Idaho 'Zee Lady' and 'Snow Giant'. Peaches in 2017:

1. Un-treated Control.

2. Terg10 mL.L-1070\%or85\%BI, where trees received Tergitol TMN-6 at 70\% bloom in 'Zee Lady' and 85\% bloom in 'Snow Giant' at the rate of $10 \mathrm{~mL} . \mathrm{L}^{-1}$.

3. Terg12.5 mL.L-1@70\%or85\%BI, where trees received Tergitol TMN-6 at 70\% bloom in 'Zee Lady' and 85\% bloom in 'Snow Giant' at the rate of $12.5 \mathrm{~mL} . \mathrm{L}^{-1}$.

4. FO20 mL.L-1 plus LS25 mL.L-1@ 70\% Bloom for 'Zee Lady' and $80 \% \mathrm{Bl}$, where trees received Crocker Fish Oil at the rate of $20 \mathrm{~mL} \cdot \mathrm{L}^{-1}$ and lime sulfur at the rate of $25 \mathrm{~mL} . \mathrm{L}^{-1}$ at $70 \%$ bloom in 'Zee Lady' and 85\% bloom in 'Snow Giant'.

5. ATS20 mL.L-1@ $070 \%$ bloom in 'Zee Lady' and $85 \%$ bloom in 'Snow Giant' at the rate of $20 \mathrm{~mL}^{\mathrm{L}} \mathrm{L}^{-1}$.

E. Treatments on 'Red Globe' and 'Elberta' Peaches in Utah, 2016:

1. Un-treated Control. 
Citation: Fallahi E, Khoddamzadeh AA, Fallahi B, et al. (2020) Branched Secondary Alcohol Ethoxylate, Ammonium Thiosulfate, Calcium polysulfides-thiosulfate, and Fish Oil Effects on Blossom Thinning, Fruit Set and Quality of Peaches and Nectarines. J Hortic Sci Res 3(1):125-134

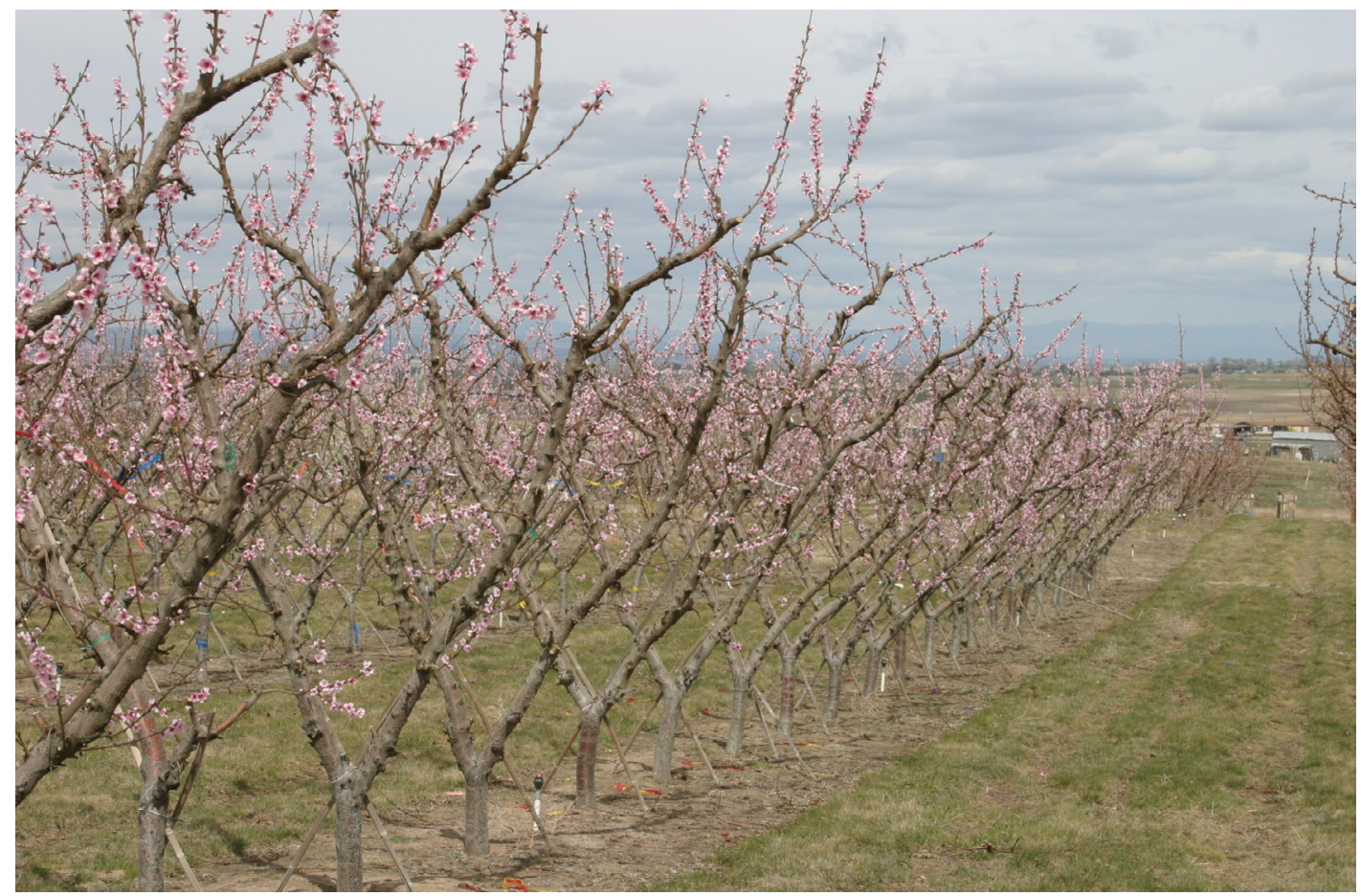

Figure 4: 'Zee Lady' peaches at the University of Idaho Orchards at 80\% bloom stage in 2016.

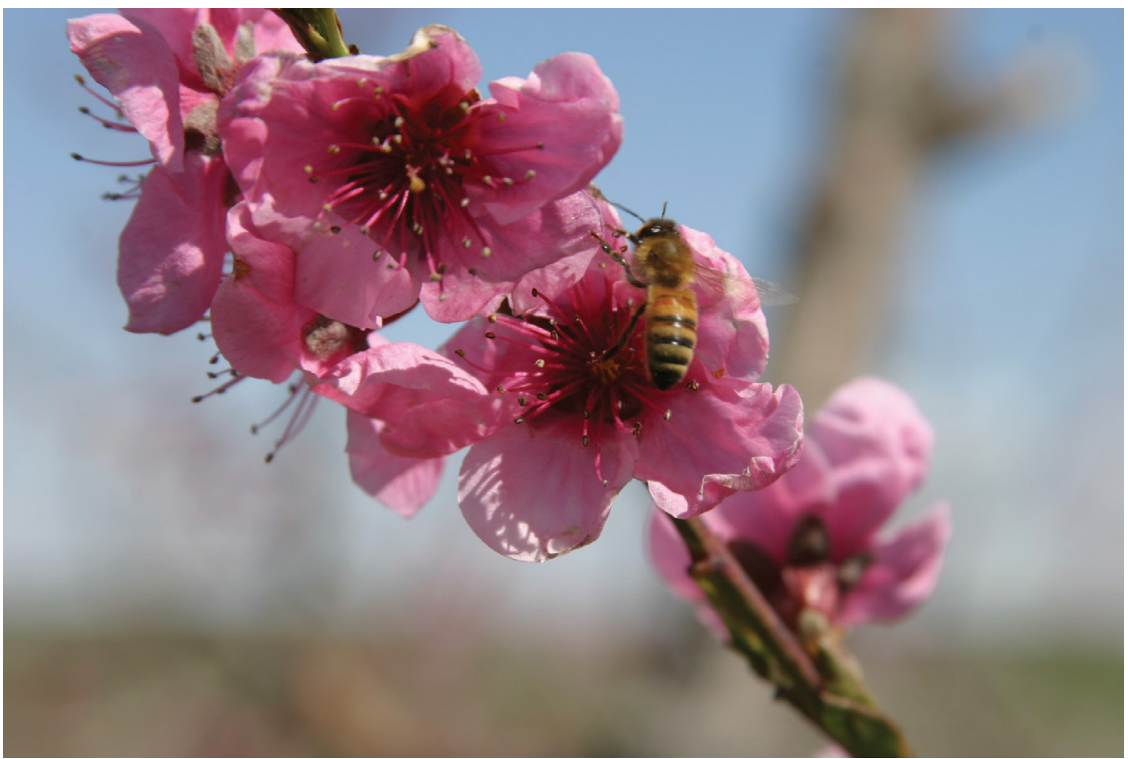

Figure 5: Stage of $100 \%$ bloom for blossom thinning study in nectarine.

2. Terg7.5 mL.L-1 @80\%Bl, where trees received Tergitol TMN-6 at $80 \%$ bloom at the rate of $7.5 \mathrm{~mL}^{-\mathrm{L}^{-1}}$.

3. Terg10 mL.L ${ }^{-1} @ 80 \% \mathrm{Bl}$, where trees received Tergitol TMN-6 at $80 \%$ bloom at the rate of $10 \mathrm{~mL} . \mathrm{L}^{-1}$.

4. Terg12 mL. $\mathrm{L}^{-1} @ 100 \% \mathrm{Bl}$, where trees received Tergitol TMN- 6 at $100 \%$ bloom at the rate of $12 \mathrm{~mL}^{-1}$.

\section{F. Treatments on 'Diamond Ray' Nectarine at Williamson Orchards, 2016:}

1. Un-treated Control.
2. Terg7.5 mL. $\mathrm{L}^{-1}$ once@ $80 \% \mathrm{Bl}$, where trees received Tergitol TMN-6 at $80 \%$ bloom at the rate of $7.5 \mathrm{~mL}^{-L^{-1}}$.

3. Terg7.5 mL.L ${ }^{-1} @ 40 \% \& 80 \% \mathrm{BI}$, where trees received Tergitol TMN- 6 at $40 \%$ and again at $80 \%$ bloom, each time at the rate of $7.5 \mathrm{~mL} \cdot \mathrm{L}^{-1}$.

4. Terg10 mL.L ${ }^{-1} @ 80 \% \mathrm{Bl}$, where trees received Tergitol TMN- 6 at $80 \%$ bloom, at the rate of $10 \mathrm{~mL} \cdot \mathrm{L}^{-1}$.

5. Terg10 mL.L-10 $40 \% \& 80 \% \mathrm{Bl}$, where trees received Tergitol TMN-6 at $40 \%$ and again at $80 \%$ bloom, each time at the rate of $10 \mathrm{~mL} . \mathrm{L}^{-1}$. 
6. Terg15 mL.L-10 100\%Bl, where trees received Tergitol TMN-6 at $100 \%$ bloom (Figure 5), at the rate of 15 mL.L ${ }^{-1}$ Tergitol TMN-6.

The experimental design in stone fruit experiments was randomized complete block design with four blocks. Each block consisted of two adjacent rows, each with 8 trees per treatment. To avoid contamination (border effect), four trees in the middle of that 8-tree segment per row were selected for sampling, although the entire eight trees received the same treatment. Also, four guard rows or buffers were put between the sets of adjacent experimental rows. Therefore, in each treatment, a total of 16 trees were used for sampling.

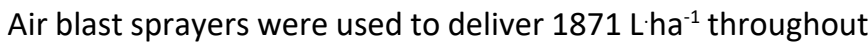
this study.

\section{Results and Discussion}

\section{Experiments on 'Summer Lady' peach in Sunny Slope}

Application of all blossom thinners treatments significantly reduced fruit set in the 'Summer Lady' peaches in both 2016 and 2017 (Table 1). In 2016 and 2017, fruit set reduction in 'Summer Lady' peach trees with a double application of Tergitol TMN-6 at the rate of $7.5 \mathrm{~mL} . \mathrm{L}^{-1}$ or $10 \mathrm{~mL} \mathrm{~L}^{-1}$, each rate at $40 \%$ and $80 \%$ bloom, were similar to those receiving a single Tergitol-TMN spray at $15 \mathrm{~mL} . \mathrm{L}^{-1}$ at $80 \%$ or $100 \%$ bloom (Table 1; Figure 6 and Figure 7). However, trees of the above-mentioned applications had significantly lower fruit set than those receiving a single application (Table 1).

Table 1: Effect of blossom thinners on fruit set in 2016 and 2017 and yield and fruit quality attributes in 2016.

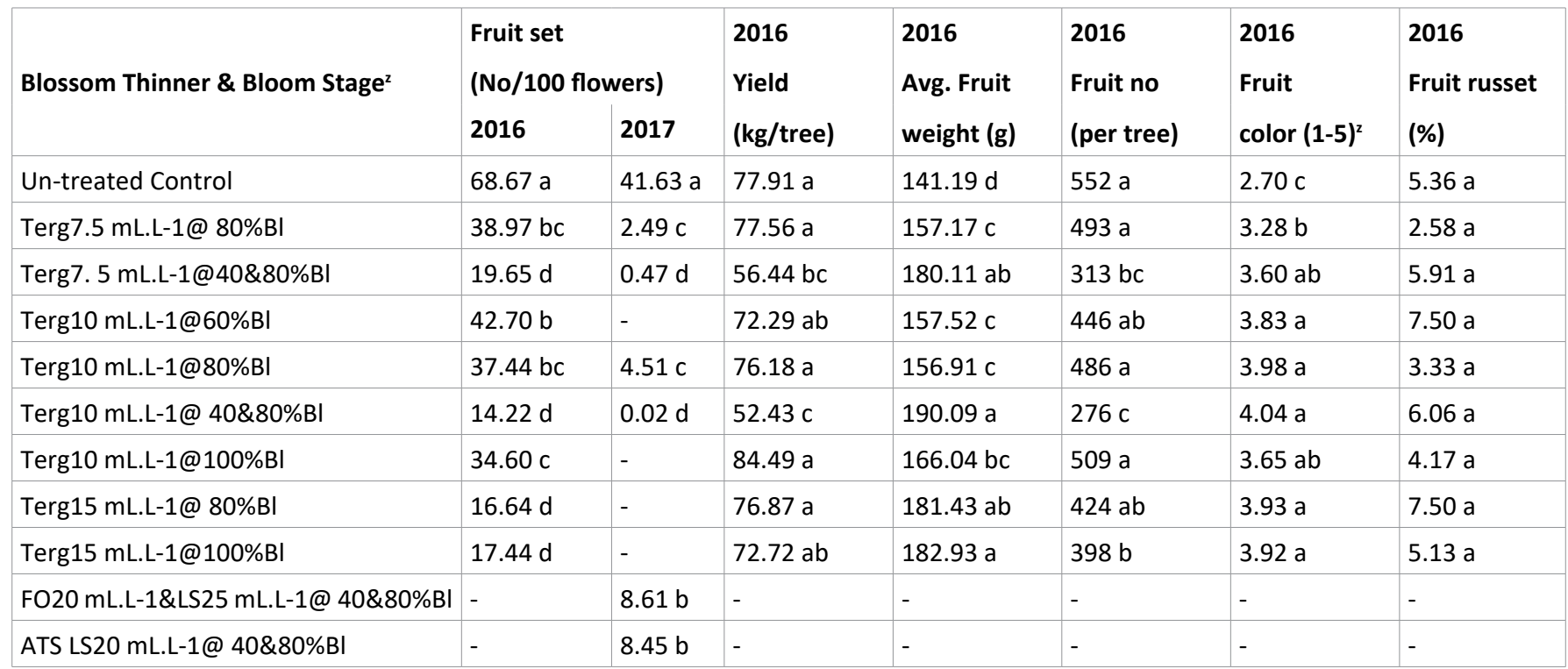

${ }^{2}$ Fruit color ranking: 1 = green, progressively to $5=$ uniform red.

${ }^{\vee}$ Mean separation within each column by LSD at $5 \%$ level.

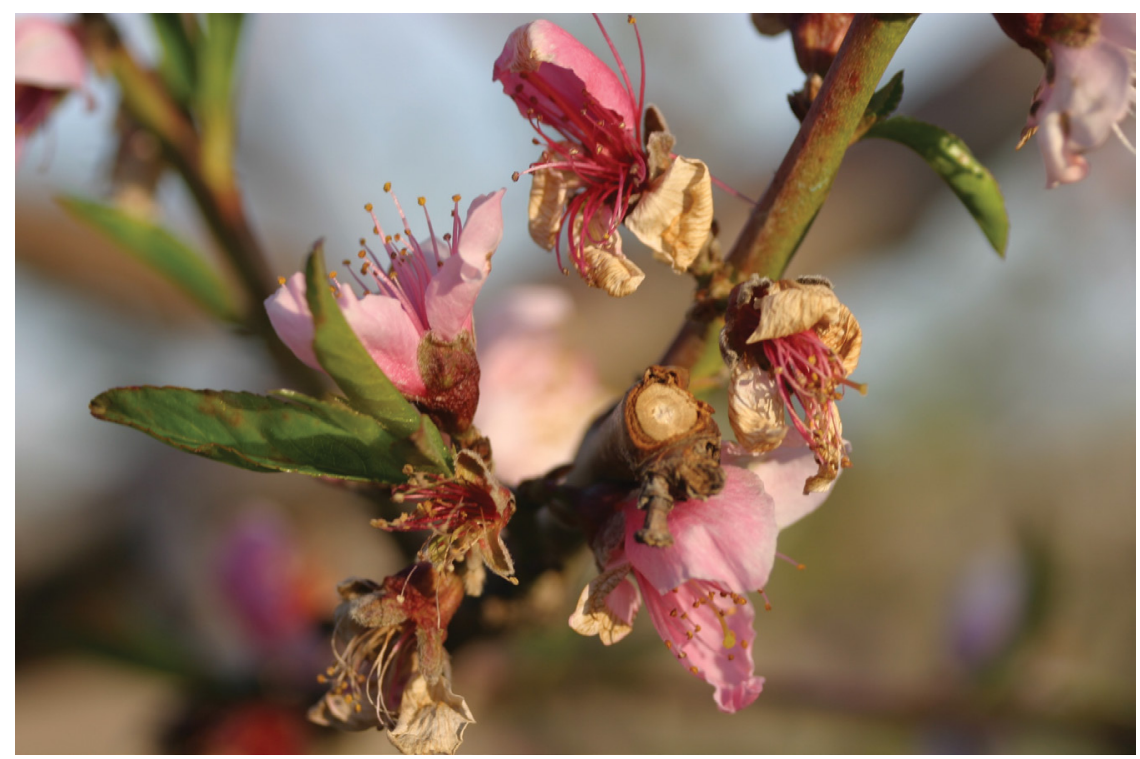

Figure 6: Caustic symptom of Tergitol TMN-6 applicatiions afterr 24-36 hours in peaches. 


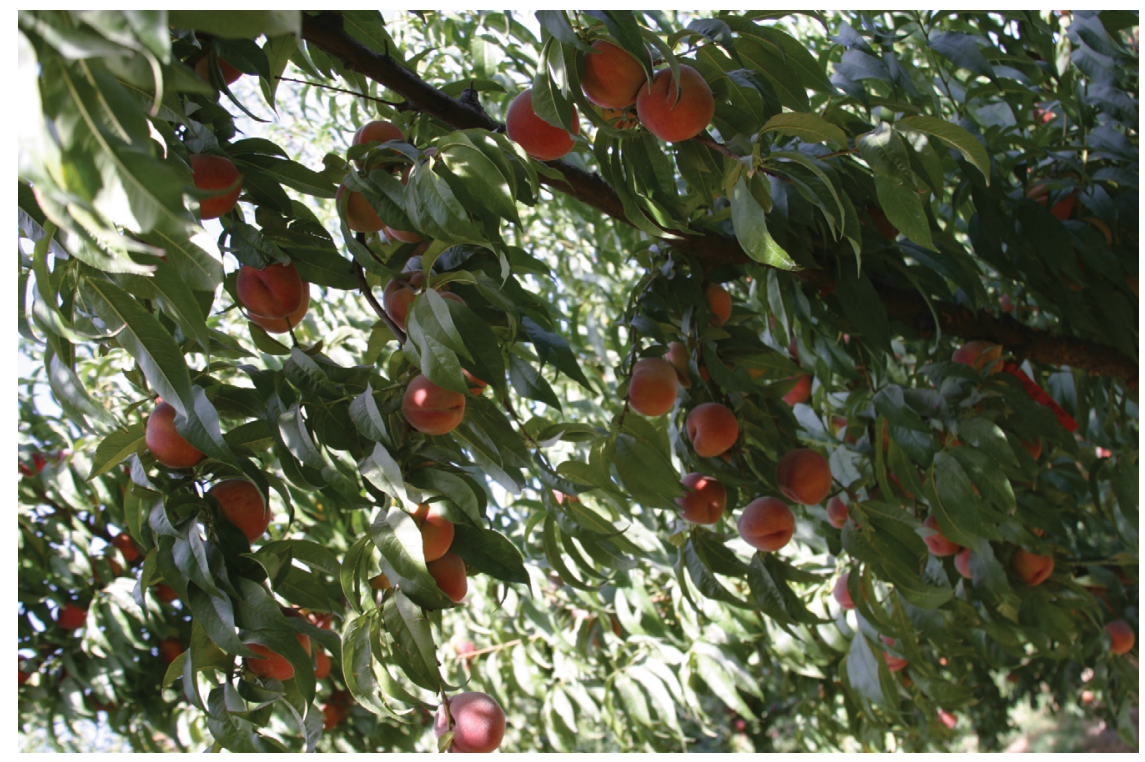

Figure 7: Harvest time picture of a 'Summer Lady' peach tree, receiving a perfect blossom thinning followed by a hand thinning in 2007.

Table 2: Effect of Tergitol TMN-6 on Fruit Set, Yield, and Fruit Quality in 'Zee Lady' Peach in 2016.

\begin{tabular}{|c|c|c|c|c|c|c|c|c|}
\hline Treatment & $\begin{array}{l}\text { Thinned } \\
\text { fruit on } \\
\text { ground } \\
\text { (\%) }\end{array}$ & $\begin{array}{c}\text { Fruit set } \\
\text { (Fruit } \\
\text { no/100 } \\
\text { flowers) }\end{array}$ & $\begin{array}{c}\text { Yield } \\
\text { (kg/tree) }\end{array}$ & $\begin{array}{c}\text { Fruit } \\
\text { russet } \\
(\%)\end{array}$ & $\begin{array}{l}\text { Avg. fruit } \\
\text { weight } \\
\text { (g) }\end{array}$ & $\begin{array}{c}\text { Fruit } \\
\text { number } \\
\text { (No/tree) }\end{array}$ & $\begin{array}{c}\text { Fruit color } \\
(1-5)^{2}\end{array}$ & $\begin{array}{c}\text { Fruit } \\
\text { russet } \\
(\%)\end{array}$ \\
\hline Un-treated Control & $81.00 a^{y}$ & $43.58 \mathrm{a}$ & $23.12 \mathrm{a}$ & $2.14 \mathrm{a}$ & $191.52 \mathrm{ab}$ & $121 \mathrm{a}$ & $3.38 \mathrm{a}$ & $2.14 \mathrm{a}$ \\
\hline Terg10 mL.L-1@60BI & $50.3 \mathrm{~b}$ & $26.10 \mathrm{~b}$ & $30.36 \mathrm{a}$ & $1.43 \mathrm{a}$ & $19.86 \mathrm{a}$ & $153 \mathrm{a}$ & $3.50 \mathrm{a}$ & $1.43 \mathrm{a}$ \\
\hline Terg10 mL.L-1@80BI & $42.67 \mathrm{c}$ & $16.25 c$ & 24.84 a & $0.01 \mathrm{a}$ & $194.81 \mathrm{a}$ & $128 \mathrm{a}$ & $3.60 \mathrm{a}$ & $0.01 \mathrm{a}$ \\
\hline Terg10 mL.L-1@100BI & $48.33 \mathrm{bc}$ & $26.00 \mathrm{~b}$ & $23.46 \mathrm{a}$ & $0.00 \mathrm{a}$ & $199.93 \mathrm{a}$ & $117 \mathrm{a}$ & $3.30 \mathrm{a}$ & $0.01 \mathrm{a}$ \\
\hline Terg12.5 mL.L-1@100BI & $52.80 \mathrm{~b}$ & $15.99 \mathrm{c}$ & $23.46 \mathrm{a}$ & $1.43 \mathrm{a}$ & $186.80 \mathrm{~b}$ & $126 \mathrm{a}$ & $3.65 \mathrm{a}$ & $1.43 \mathrm{a}$ \\
\hline
\end{tabular}

${ }^{2}$ Fruit color ranking: 1 = green, progressively to $5=$ uniform red.

'Mean separation within each column by LSD at $5 \%$ level.

Table 3: Effect of Fish Oil, Ammonium thiosulfate, and Tergitol TMN-6 on fruit set in 'Zee Lady' peach at 70\% bloom and 'Snow Giant' peaches at $85 \%$ bloom in 2017.

\begin{tabular}{|l|l|l|}
\hline \multicolumn{1}{|c|}{ Treatment } & $\begin{array}{l}\text { Fruit set in 'Zee Lady' at 70\% bloom } \\
\text { (Fruit/100 flower) }\end{array}$ & $\begin{array}{l}\text { Fruit set in 'Snow Giant' at 85\% bloom } \\
\text { (Fruit/100 flower) }\end{array}$ \\
\hline Un-treated Control & $41.57 \mathrm{a}^{2}$ & $45.50 \mathrm{a}$ \\
\hline FO20 mL.L-1 plus LS25 mL.L-1@ 70\%BIZL80\%BISG & $36.23 \mathrm{a}$ & $41.84 \mathrm{ab}$ \\
\hline ATS20 mL.L-1@70\% BIZL80\%BISG & $33.40 \mathrm{ab}$ & $37.21 \mathrm{~b}$ \\
\hline Terg10 mL.L-1@70BIZL80\%SG & $25.80 \mathrm{bc}$ & $19.18 \mathrm{c}$ \\
\hline Terg12.5 mL.L-1@70BIZL80\%SG & $21.33 \mathrm{c}$ & $17.37 \mathrm{c}$ \\
\hline
\end{tabular}

${ }^{2}$ Mean separation within each column by LSD at $5 \%$ level.

Trees receiving Fish Oil at $20 \mathrm{~mL}^{-1}$ plus lime sulfur at 25 $\mathrm{mL} . \mathrm{L}^{-1}$, once at $40 \%$ bloom and again at $80 \%$ bloom reduced fruit set as compared to Un-treated Control but, the fruit set was higher than those with any Tergitol-TMN-6 spray in 2017 (Table 2).

Total yield was proportional to the severity of thinning and final fruit weight (Table 1). Trees in Un-treated Control had the highest number of fruit but lowest fruit weight control trees, 2). Application of Tergitol at $10 \mathrm{~mL} . \mathrm{L}^{-1}$ at $40 \%$ and $80 \%$ bloom cased overthinning in both 2016 and 2017 and resulted in production of largest fruit but lower number of fruit and yield per tree in 2016 (Table 2). Thus, this rate and frequency is not recommended for 'Summer Lady' peach blossom thinning. Based on our experience (not published) and another report [18], a marketable medium-large 'Summer 
Citation: Fallahi E, Khoddamzadeh AA, Fallahi B, et al. (2020) Branched Secondary Alcohol Ethoxylate, Ammonium Thiosulfate, Calcium polysulfides-thiosulfate, and Fish Oil Effects on Blossom Thinning, Fruit Set and Quality of Peaches and Nectarines. J Hortic Sci Res 3(1):125-134

Lady' peach fruit would weigh about 166-176 grams. Trees receiving Terg10 mL.L-1@100\%Bl, Terg15 mL.L-1@80\%BI, and Terg15 mL.L-1@100\%Bl had average fruit weight above 166 $\mathrm{g}$ and yield above $72 \mathrm{~kg} /$ tree, without any adverse effects of fruit color or russeting in 2016 (Table 2), and can be considered optimum rates and bloom stage for Tergitol TMN-6 sprays. However, If the market demands for smaller fruit size with the same yield threshold (i.e. fruit size of above $156 \mathrm{~g}$ and yield of above $72 \mathrm{~kg} /$ tree), application of Terg7.5 mL.L ${ }^{1} @ 80 \% \mathrm{BI}$, Terg10 mL.L-1@60\%Bl, and Terg10 mL.L-1 @80\%BI would be suitable. In these cases, the numbers of fruit per tree were between 398 and 509 (Table 2). Based on this study, double applications of Terg7.5 mL.L $\mathrm{L}^{-1}$ or higher did resulted in larger fruit size but drastically reduced yield. Thus, a double application should only be applied when the market demands and justifies for larger fruits with lower yield.

\section{Experiments on 'Zee Lady' and 'Snow Giant' peaches at the University of Idaho}

Comparing to trees of Un-treated Control, trees receiving Tergitot TMN-6 at $12.5 \mathrm{~mL} . \mathrm{L}^{-1}$ at $100 \%$ bloom or $10 \mathrm{~mL} . \mathrm{L}^{-1}$ at all bloom stages of bloom in 2016 (Terg10 mL.L-1@60\%Bl, Terg10 mL.L-1 @80\%BI, Terg10 mL.L-1 @100\%BI, Terg12.5 mL.L $\left.{ }^{1} @ 100 \% \mathrm{~B}\right)$ and Tergitol at $10 \mathrm{~mL} . \mathrm{L}^{-1}$ or $12.5 \mathrm{~mL} \cdot \mathrm{L}^{-1}$ at $70 \%$ bloom in 2017 (Table 3) significantly reduced fruit set in 'Zee Lady' and 'Snow Giant' peaches. In 'Zee Lady', the percentages of fruit dropped on the ground (PFDG) in each treatment approximately mirrored its fruit set percentage in 2016. Thus, trees in Un-treated Control had significantly higher was significantly higher (PFDG) than all other treatments (Table 2).

It is noteworthy that in 'Zee Lady' peach, applications of Tegitol at $60 \%$ or $100 \%$ bloom (Terg10 mL.L-1 @60\%Bl or Terg10 $\left.m L . L^{-1} @ 100 \% B I\right)$ were less effective on thinning than the sprays of Terg10 mL.L-1@80\%BI or Terg12.5 mL.L-1@100\%BI in 2016 (Table 2). This result implies that a single application of at Tergitol TMN-6 to 'Zee Lady' peach at $10 \mathrm{~mL} . \mathrm{L}^{-1}$ at $60 \%$ bloom is too early, as blooms are not sufficiently open and pollinized. Also, application of Tergitol TMN-6 to 'Zee Lady' peach at $10 \mathrm{~mL} \cdot \mathrm{L}^{-1}$ at $100 \%$ bloom is too late as most flowers are already fertilized and they cannot be sufficiently thinned at this rate. Nevertheless, when the rate was increased to $12.5 \mathrm{~mL} . \mathrm{L}^{-1}$, this chemical significantly reduced fruit set of 'Zee Lady' peach even at $100 \%$ bloom in 2016 . However, when 'Snow Giant' trees were at $100 \%$ bloom stage, application of Tergitol TMN-6 at $12.5 \mathrm{~mL} . \mathrm{L}^{-1}$ resulted in significantly lower fruit set as compared to all other treatments in 2016 (Table 4). Also, application of Tergitol at $10.0 \mathrm{~mL}^{-L^{-1}}$ at $100 \%$ bloom effectively reduced fruit set in 'Snow Giant'. This comparison reveals that 'Snow Giant' peach is more sensitive than 'Zee Lady' to the same stage of bloom and concentrations of Tergitol TMN-6. Therefore, response of cultivar, concentration of blossom thinner and stage of blooms are all crucial in the success or failure of blossom thinning. In general, the results of Tergitol TMN-6 on peach thinning in this study agreed with our previous report with a different group of peach cultivars [2].

In 'Zee Lady', trees receiving Tergitol TMN-6 at $1.25 \mathrm{~mL} . \mathrm{L}^{-1}$ at $100 \%$ bloom had smaller fruit (Table 2 ), perhaps because this rate resulted in minor leaf burning, reducing carbohydrate deposit into the fruit tissues. Nevertheless, in 'Snow Giant', trees receiving Tergitol TMN-6 at all concentrations and blossom stages had significantly higher fruit weight as compared to the trees of Un-treated Control (Table 4). Application of Tergitol TMN-6 did not affect fruit russeting in 'Zee Lady' (Table 2) while tended to increase russeting in 'Snow

Table 4: Effect of Tergitol TMN-6 on fruit set, yield, and fruit quality at harvest in 'Snow Giant' peach in 2016.

\begin{tabular}{|l|l|l|l|l|l|}
\hline \multicolumn{1}{|c|}{ Treatment } & \multicolumn{1}{|c|}{$\begin{array}{c}\text { Fruit set } \\
\text { (No./100 flowers) }\end{array}$} & Yield (kg/tree) & \multicolumn{1}{|c|}{ Fruit weight (g) } & \multicolumn{1}{c|}{$\begin{array}{c}\text { Color } \\
\text { (1-5) }\end{array}$} \\
\hline Un-treated Control & $67.67 \mathrm{a}^{\mathbf{2}}$ & $23.22 \mathrm{a}$ & $216.85 \mathrm{~b}$ & $2.28 \mathrm{a}$ & $1.39 \mathrm{~b}$ \\
\hline Terg10 mL.L-1@60BI & $57.55 \mathrm{~b}$ & $23.33 \mathrm{a}$ & $243.92 \mathrm{a}$ & $2.39 \mathrm{a}$ & $4.72 \mathrm{ab}$ \\
\hline Terg10 mL.L-1@80BI & $54.79 \mathrm{bc}$ & $23.39 \mathrm{a}$ & $236.11 \mathrm{a}$ & $2.33 \mathrm{a}$ & $5.84 \mathrm{a}$ \\
\hline Terg10 mL.L-1@100BI & $49.97 \mathrm{c}$ & $23.45 \mathrm{a}$ & $242.03 \mathrm{a}$ & $2.41 \mathrm{a}$ & $3.95 \mathrm{ab}$ \\
\hline Terg12.5 mL.L-1@100BI & $43.18 \mathrm{~d}$ & $22.05 \mathrm{a}$ & $242.51 \mathrm{a}$ & $2.43 \mathrm{a}$ & $6.95 \mathrm{a}$ \\
\hline
\end{tabular}

${ }^{2}$ Fruit color ranking: 1 = green, progressively to $5=$ uniform red.

'Mean separation within each column by LSD at $5 \%$ level.

Table 5: Effect of Tergitol TMN-6 on fruit set of 'Red Globe' and 'Elberta' in peaches in Utah, 2016.

\begin{tabular}{|l|l|l|}
\hline Treat & $\begin{array}{l}\text { Red Globe fruit set } \\
\text { (Fruit no./100 flowers) }\end{array}$ & $\begin{array}{l}\text { Elberta uit set } \\
\text { (Fruit no/100 flowers) }\end{array}$ \\
\hline Un-treated Control & $65.49 \mathrm{a}^{2}$ & $50.26 \mathrm{a}$ \\
\hline Terg7.5 mL.L-1@80\%BI & $46.81 \mathrm{~b}$ & $33.48 \mathrm{~b}$ \\
\hline Terg10 mL.L-1@80\%BI & $43.23 \mathrm{bc}$ & $32.76 \mathrm{~b}$ \\
\hline Terg12.5mL:L1@80\%BI & $35.57 \mathrm{c}$ & $27.39 \mathrm{~b}$ \\
\hline
\end{tabular}

${ }^{2}$ Mean separation within each column by LSD at $5 \%$ level. 
Citation: Fallahi E, Khoddamzadeh AA, Fallahi B, et al. (2020) Branched Secondary Alcohol Ethoxylate, Ammonium Thiosulfate, Calcium polysulfides-thiosulfate, and Fish Oil Effects on Blossom Thinning, Fruit Set and Quality of Peaches and Nectarines. J Hortic Sci Res 3(1):125-134

Table 6: Effect of Tergitol TMN-6 on fruit set, yield, and fruit quality in nectarine at harvest, 2016.

\begin{tabular}{|c|c|c|c|c|c|}
\hline Treat & $\begin{array}{l}\text { Fruit Set } \\
\text { (Fruit no./100 flowers) }\end{array}$ & $\begin{array}{l}\text { Yield } \\
\text { (kg/tree) }\end{array}$ & $\begin{array}{l}\text { Avg. } \\
\text { Fruit weight (g) }\end{array}$ & $\begin{array}{l}\text { Color } \\
(1-5)^{2}\end{array}$ & $\begin{array}{c}\text { Russet } \\
(\%)\end{array}$ \\
\hline Un-treated Control & $50.87 b^{y}$ & $43.71 \mathrm{a}$ & $136.06 \mathrm{c}$ & $2.50 \mathrm{c}$ & $9.87 \mathrm{c}$ \\
\hline Terg7.5 mL.L-1@80\%BI & $14.40 \mathrm{~b}$ & $29.17 \mathrm{~b}$ & $156.67 a b$ & $2.75 a b c$ & $20.83 \mathrm{~b}$ \\
\hline Terg7.5 mL.L-1@40\%\&80\%BI & $10.86 \mathrm{bc}$ & $28.47 b$ & $149.04 \mathrm{ab}$ & $2.92 \mathrm{abc}$ & $21.49 \mathrm{~b}$ \\
\hline Terg10 mL.L-1@80\%BI & $9.82 \mathrm{bc}$ & $22.91 b c$ & $145.98 \mathrm{bc}$ & $2.64 \mathrm{bc}$ & $22.99 \mathrm{~b}$ \\
\hline Terg10 mL.L-1@40\%\&80\%BI & $8.49 \mathrm{bc}$ & $16.65 c$ & $159.05 \mathrm{a}$ & $3.00 \mathrm{ab}$ & $32.57 \mathrm{a}$ \\
\hline Terg10 mL.L-1@40\%\&80\%BI & $8.49 \mathrm{bc}$ & $16.65 c$ & $159.05 \mathrm{a}$ & $3.00 \mathrm{ab}$ & $32.57 \mathrm{a}$ \\
\hline Terg15 mL.L-1@100\%BI & $5.39 \mathrm{c}$ & $21.53 \mathrm{bc}$ & $151.44 a b$ & $3.16 \mathrm{a}$ & $24.61 \mathrm{ab}$ \\
\hline
\end{tabular}

${ }^{2}$ Fruit color ranking: $1=$ green, progressively to $5=$ uniform red.

vMean separation within each column by LSD at $5 \%$ level.

Giant' fruit in 20016 (Table 4). This observation is particularly important when 'Snow Giant' white-fleshed peach is produced for the Asian market. This market usually mandates blemish-free or fruit with minimum russet.

Yield and fruit color were not influenced by Tergitol TMN6 application at any rate or blossom stage in either 'Zee Lady' (Table 2) or 'Snow Giant' peach (Table 4) in 2016 because fruits in all trees in this study were hand-thinned to establish a $15-18 \mathrm{~cm}$ spacing between fruits.

\section{Experiments on 'Red Globe' and 'Elbrta' peaches, Utah}

Comparing with untreated-control, applications of Tergitol TMN-6 at all concentrations at $80 \%$ bloom significantly reduced fruit set (Table 5 ) and increased fruit weight but did not affect yield in 'Red Globe' and 'Elberta' peaches in Utah (data not shown). The fruit set reduction was inversely proportional to the rate of application in these cultivars in 2016 (Table 5).

\section{Experiments on 'Diamond Ray' nectarine}

Application of Tergitol TMN-6 at all rates and bloom stages significantly reduced fruit set and yield but increased fruit weight, color, and russet in 'Diamond Ray' nectarine in 2016, although differences were not always significant (Table 6). Production of russet-free fruit in nectarines is extremely critical for export market but this practice is one of the most difficult tasks facing fruit growers. Application of Tergitol TMN6 at $7.5 \mathrm{~mL}^{-1} \mathrm{~L}^{-1}$, either once at $80 \%$ bloom or twice, at $40 \%$ and again at $80 \%$, produced relatively large fruit size and high yields, while had lower fruit russet than other rates $(20.83 \%$ and $21.49 \%$, respectively (Table 6 ). Thus, if low levels of russeting could be tolerated in this nectarine, Tergitol TMN- 6 at $7.5 \mathrm{~mL} . \mathrm{L}^{-1}$ can be used to reduce the fruit set and cost of production and increase the net return.

\section{General Remarks and Conclusions}

Stage of bloom, temperature, bee activity, varietal differences, tree vigor, and spray volume are among factors influencing the effectiveness of blossom thinning in apples and stone fruit [4]. Temperature affects bee activity and thus, the number of fertilized flowers. In this study, when the condi- tions are in favor of heavy fruit set, it seemed that applications of Tergitol TMN-6 at $10 \mathrm{~mL} . \mathrm{L}^{-1}$ at $80 \%$ bloom or $12.5 \mathrm{~mL} . \mathrm{L}^{-1}$ at $100 \%$ bloom, led to optimum thinning. However, when the chance of pollination and fruit set is likely but uncertain, and there is a risk of moderate frost injury during pollination and after fruit set, an application of lime sulfur at $25 \mathrm{~mL}^{-1}$ at $70 \%$ to $85 \%$ bloom may be enough. One should be cautious about fruit marking and leaf burning with the application of blossom thinners.

Fine-tuning and a timely application of Tergitol TMN-6 can be economically sound. However, early applications of this chemical, before enough pollination and fertilization may lead to major losses. Additional research on blossom thinning is also warranted to determine a method for a quick determination of the proper blossom stage based on physiological development of pollen tube and/or fertilization of the ovules.

\section{Acknowledgement}

The author wishes to express his gratitude to the Idaho Apple Commission and the Idaho Agricultural Experiment Station for their financial support of this project. Contribution of materials, labor, and donation of considerable amount of fruit by several Idaho fruit growing companies, including Symms Fruit Ranch, Williamson Orchards, Henggeler Fruit Packing House, Trail Orchards, and J.C. Watson's Company to this project is gratefully appreciated.

\section{References}

1. Hildebrand EM (1944) The mode of action of the pollenicide, Elgetol. Proc. Amer. Soc. Hort. Sci 45: 53-58.

2. Fallahi E (1997) Application of endothallic acid, pelargonic acid, and hydrogen cyanamide for blossom thinning in apple and peach. HortTechnology 7: 395-399.

3. Fallahi E, Williams MW, Colt WM (1997) Blossom thinning of 'Law Rome Beauty' apple with hydrogen cyanamide and monocarbamide dihydrogensulfate. J. Tree Fruit Prod 2: 33-44.

4. Fallahi E, Willemsen K (2002) Blossom thinning of pome and stone fruit HortScience 37: 474-476.

5. Fallahi E, Kilby M, Moon JW (1990) Effects of various chemicals on dormancy, maturity and thinning of peaches. Deciduous Fruit and Nut: 121-128. 
Citation: Fallahi E, Khoddamzadeh AA, Fallahi B, et al. (2020) Branched Secondary Alcohol Ethoxylate, Ammonium Thiosulfate, Calcium polysulfides-thiosulfate, and Fish Oil Effects on Blossom Thinning, Fruit Set and Quality of Peaches and Nectarines. J Hortic Sci Res 3(1):125-134

6. Fallahi E, Simons BR, Fellman JK, Colt WM (1992) Use of hydrogen cyanamide for apple and plum thinning. Plant Growth Regular 11: 435-439.

7. Fallahi E, Lee RR, Lee GA (1998) Commercial-scale use of hydrogen cyanamide for blossom thinning of apple and peach. HortTechnology 8: 556-560.

8. Warner G (1998) Consistent tonnage needed for profitability. Good Fruit Grower 49: 9-10.

9. Fallahi $E$ (1998) The use of blossom thinners for regular cropping deciduous fruit trees. Proc. Plant Growth Regulation Society of America: 27-33.

10. Greene D, Hauschild WKI, Krupa J (2001) Effect of blossom thinners on fruit set and fruit size of peaches. HortTechnology 11: 179-183.

11. Southwick SM, Weis KG, Yeager JT, et al. (1998) Blossom thinning of 'Loadel' cling peach with a surfactant: Effects of concen- tration, carrier volume, and differential applications within the canopy. HortTechnology 8: 55-58.

12. Byers RE, Lyons Jr CG (1985) Peach flower thinning and possible sites of action of desiccating chemicals. J. Amer. Soc. Hort. Sci 110: 662-667.

13. Fallahi E, Fallahi B, McFerson JR, et al. (2016) Tergitol-TMN-6 surfactant Is an effective blossom thinner for stone fruits. HortScience 5: 1243-1248.

14. Wilkins BS, Ebel RC, Dozier WA, et al. (2004) Tergitol-TMN-6 for thinning peach blossoms. HortScience 39: 1611-1613.

15. Miller SS, Tworkoski T (2010) Blossom thinning in apple and peach with essential oil. HortScience 45: 1218-1225.

16. https://blogs.ext.vt.edu/tree-fruit-horticulture/2020/03/28/apple-blossom-thinning-general-overview-and-updates/

17. http://tfrec.cahnrs.wsu.edu/

18. https://hannaone.com/Recipe/weightpeaches.html

DOI: $10.36959 / 745 / 407$

Copyright: (C) 2020 Fallahi E, et al. This is an open-access article distributed under the terms of the Creative Commons Attribution License, which permits unrestricted use, distribution, and reproduction in any medium, provided the original author and source are credited. 